\title{
IDENTIFIKASI PRIORITAS PENGEMBANGAN AGROWISATA BANGKA BOTANICAL GARDEN (BBG) KOTA PANGKALPINANG
}

\author{
Nanang Wahyudin ${ }^{(1)}$, Muhammad Faisal Akbar ${ }^{(2)}$, Sugiharti ${ }^{(3)}$ \\ (1) \& (2) Universitas Bangka Belitung, \\ (3) Sekolah Tinggi Ilmu Ekonomi Totalwin Semarang \\ nanang.w19@gmail.com, m faisal.akbar@yahoo.com, sugih_arti1@yahoo.com
}

Submitted: 15 December 2019 Revised:17 March 2020

Accepted :20 March 2020

\begin{abstract}
ABSTRAK
Masuknya Bangka Botanical Garden (BBG) dalam nominasi anugerah pesona Indonesia ke IV tahun 2019 menjadi peluang bagi destinasi pariwisata Kota Pangkalpinang untuk meningkatkan kunjungan wisatawan nusantara maupun mancanegara, dalam rangka mendukung percepatan pengembangan perbaikan destinasi pariwisata BBG perlu diidentifikasi potensi dan prioritas pengembangan perbaikaan yang tepat sasaran, Penelitian ini dilakukan diwilayah pangkalpinang objek utamanya yaitu agrowisata Bangka Botanical Garden (BBG), adapun teknik pengambilan sampel non probability sampling dengan metode Convenience Sampling sehingga ditetapkan jumlah sampel sebesar 60 responden, untuk melihat potensi serta kelemahan secara detail menggunakan analisis IPA (Importance Performance Analysis) yang akhirnya menghasilkan prioritas yang perlu dilakukan perbaikan. Adapun hasil penelitian menemukan perioritas utama perbaikan ialah layanan fasilitas umum (Kuantitas kualitas toilet, tempat sampah dan kondisi jalan objek wisata) serta program promosi yang membranding BBG menjadi Agrowisata Unggulan Kota Pangkalpinang.
\end{abstract}

Kata Kunci: Agrowisata, BBG, Important Performance Analysis, Strategi

\section{IDENTIFICATION OF THE PRIORITY OF BANGKA BOTANICAL GARDEN (BBG) DEVELOPMENT PANGKALPINANG CITY}

\begin{abstract}
The inclusion of Bangka Botanical Garden (BBG) in the nomination of the Anugrah Pesona Indonesia IV in 2019 becomes an opportunity for Pangkal Pinang City tourism destinations to increase domestic and foreign tourist visits, in order to support the acceleration of the development of BBG tourism destination improvements, it is necessary to identify the potential and priority of development that is right on target. This research was conducted in the base area of the main object, namely Bangka Botanical Garden (BBG) agrotourism, while the non-probability sampling technique using Convenience Sampling method so that the sample size of 60 respondents was determined, to see the potential and weakness in detail using IPA analysis (Importance Performance Analysis) which ultimately results in priorities that need improvement. The results of the study found that the main priority of improvement is public facilities services (Quantity of quality of toilets, trash bins and the condition of tourist attraction roads) as well as promotion programs that are comparing $B B G$ to Pangkalpinang City's Superior AgroTourism.
\end{abstract}

Keywords: Agrotourism, BBG Important Performance Analysis, Strategy 
Nanang Wahyudin, Muhammad Faisal Akbar, dan Sugiharti : Identifikasi Prioritas

Pengembangan Agrowisata Bangka Botanical Garden (BBG) Kota Pangkalpinang

\section{PENDAHULUAN}

Inklusivitas ekonomi pada sektor pariwisata Pangkalpinang mengalami perkembangan yang cukup pesat dalam 5 tahun terakhir. Terdapat beberapa destinasi wisata yang telah berkembang dengan pangsa pasar yang cukup besar dan didominasi oleh pengunjung lokal. (Nanang et al) Sektor Pariwisata merupakan salah satu sektor yang bisa menjadi sumber pendapatan dan lapangan pekerjaan bagi perekonomian lokal (Chang, Khamkaev, \& McAleer, 2010). Pengembangan pariwisata yang baik mampu melibatkan semua lapisan masyarakat menyiratkan bahwa sektor ini mampu menjadi suatu ekosistem yang luas dalam melakukan pembangunan ekonomi yang berkelanjutan (Basiago, 1999; Yunis, 2009).

Destinasi wisata Bangka Botanical Garden (BBG) merupakan salah satu agrowisata favorit di Bangka Belitung yang memiliki area hijau seluas 300 hektar dan memiliki letak yang cukup strategis. Salah satu daya tarik wisatawan lokal ke tempat destinasi ini karena suasana yang terdapat di BBG sejuk dan para wisatawan yang berkunjung sekaligus memberikan edukasi usaha mengenai pertanian, pertenakan dan perikanan yang saat ini sudah berjalan dengan baik.

Bangka Botanical Garden (BBG) merupakan salah satu destinasi wisata yang mengalami perkembangan sangat pesat pada 3 tahun terakhir. Salah satu faktor utama perkembangan yang dialami oleh BBG adalah ketersediaan jasa UMKM yang bergerak dibidang jasa makanan yang menyediakan produk olahan baik berupa, buah buahan hasil kebun, serta makanan olahan ikan yang dibuat secara tradisional dan memiliki segmentasi low commercial services. Implikasi dari pengelolaan jasa makanan dengan harga yang terjangkau adalah tingkat permintaan yang cukup tinggi dari wisatawan. Diketahui bahwa mayoritas pengunjung BBG pada umumnya adalah wisatawan lokal.
Turis lokal adalah turis yang melakukan pelesiran dan berasal dari dalam daerah itu sendiri. Berdasarkan tujuan dari melakukan pelesiran, turis lokal memiliki tiga tipe yaitu: common interest tourism, holiday tourist dan business tourist (Kumar, 2016). Penelitian ini lebih melakukan pendekattan pada 2 tipe turis yang telah dijelaskan sebelumnya. Yaitu common interest tourist yang lebih melakukan pelesiran hanya sebatas mengobrol dengan rekan, teman dan keluarga dengan tidak terlalu menekankan pada fasilitas dan keindahan destinasinya melainkan tempat yang umum, mudah dijangkau dan sesuai dengan anggaran yang disiapkan. Selanjutnya adalah holiday tourism dengan karakter yang lebih menggunakan waktu senggangnya untuk melihat-lihat, rekreasi dan bermain bersama keluarga.

BBG memiliki beberapa kelebihan khususnya dari sisi daya tariknya. Hasil survei menunjukan bahwa BBG mudah diakses oleh wisatawan karena kondisi infrastruktur yang sudah baik, pemandangan yang indah, harga makanan yang relatif murah serta tingkat keamanan yang terjaga dengan baik (Nanang et al:2019). Beberapa kualifikasi yang dimiliki oleh BBG membuat destinasi ini memiliki potensi yang cukup besar untuk dikembangkan dan pada jangka Panjang menjadi daya tarik tidak hanya untuk wisatawan lokal namun juga wisatawan asing. Masuknya BBG ke dalam nominasi anugerah pesona Indonesia merupakan pembuktian daya tarik yang populer.

\section{TINJAUAN PUSTAKA}

Anugerah Pesona Indonesia merupakan Ajang Pariwisata Terpopuler Indonesia yang diadakan setiap tahun dan didukung penuh oleh Kementerian Pariwisata RI, adapun kegiatannya dilakukan dalam bentuk pemberian penghargaan kepada destinasi Wisata Terpopuler di Indonesia (anugerahpesonaindonesia.com,2019).

kategori ekowisata popular tahun 2019 telah terpilih 10 nominasi ekowisata populer yaitu 
Bangka Botanical Garden - Kota Pangkal Pinang, Buukit Bangkirai - Kab. Kutai Kartanegara, Hutan Meranti Putih - Kab. Kotabaru, Kampung Flory - Kab. Sleman, Mangroove Forest Park - Kota Langsa, Mangrove Pahawang - Kab. Pesawaran, Pulau Lusi - Kab. Sidoarjo, Silimalombu Ecovillage - Kab. Samosir, Suaka Margasatwa Kerumutan - Kab. Pelalawan, TN Lore Lindu - Kab. Sigi, masuknya BBG dalam nominasi anugerah pesona Indonesia ke IV tahun 2019 menjadi peluang bagi destinasi pariwisata untuk meningkatkan kunjungan wisatawan nusantara maupun mancanegara. Berdasarkan latar belakang dan dalam rangka mendukung percepatan pengembangan perbaikan destinasi pariwisata BBG perlu diidentifikasi potensi prioritas pengembangan perbaikaan yang tepat sasaran.

\section{METODE}

Penelitian ini dilakukan diwilayah pangkalpinang objek utamanya yaitu agrowisata Bangka Botanical Garden (BBG), adapun teknik pengambilan sampel non probability sampling dengan metode Convenience Sampling (Sugiarto dkk, 2003) sehingga ditetapkan jumlah sampel sebesar 60 responden, penelitian ini menggunakan data primer dan skunder dengan pendekatan kualitatif deskriptif, dapat dilihat berikut ini:

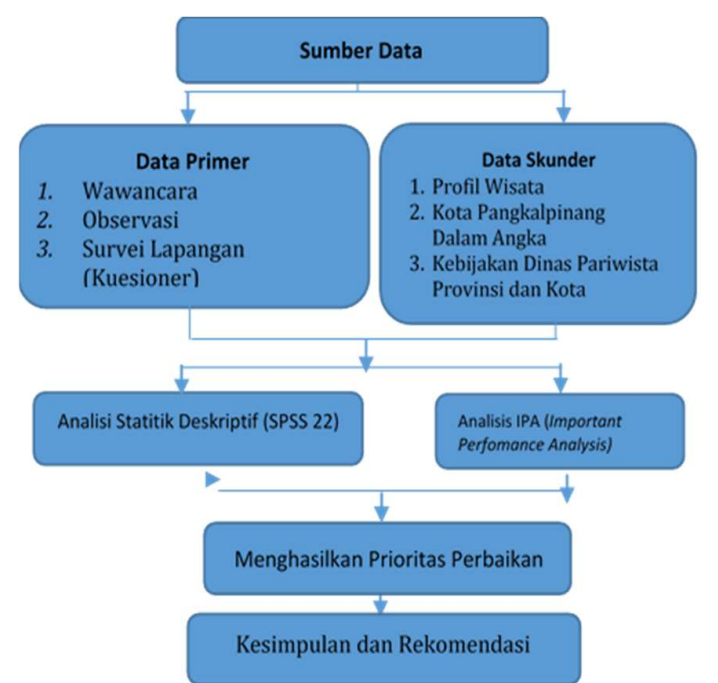

Gambar 1. Diagram Konsep Metodologi Penelitian
Proses analisis diawali dengan analisis deskriptif untuk menggambarkan kondisi umum agrowisata BBG dengan alat bantuan analisis SPSS, dan untuk melihat potensi serta kelemahan secara detail menggunakan analisis IPA (Importance Performance Analysis) yang akhirnya menghasilkan prioritas yang perlu dilakukan perbaikan. Penelitian ini dimulai dengan mengidentifikasi pengunjung mengetahui tingkat kepentingan/harapan dan kinerja/kepuasan mereka dengan menggunakan metode IPA. Hasil analisis IPA digunakan sebagai referensi untuk mengidentifaikasi potensi dan kondisi agrowista BBG.

\section{HASIL DAN PEMBAHASAN Gambaran Umum Responden Pantai Pasir Padi}

Gambaran umum responden di Bangka Botanical Garden memberikan gambaran yang sangat menarik sehingga dapat menjadi pendukung hasil analisis datanya, adapaun gambaran responden berdasarkan hasil survey dilapangan, jumlah pengunjung berdasarkan jenis kelamin terjadi perbedaan yang signifikan didominasi oleh perempuan sebanyak $60 \%$ artinya wisata ini sangat diminati oleh kaum perempuan, sedangkan dari sisi usia di dominasi $48 \%$ oleh usia 15 tahun sampai dengan 23 tahun hal tersebut menunjukan usia remaja yang mengartikan banyak pengunjung ke BBG salah satunya ialah untuk berswafoto, namun demikian usia 24-32 yang merupakan usia dewasa yang juga cukup banyak berkunjugn, dilihat dari sisi pekerjaan di dominasi pegawai 32\% dan pelajar 24\% sedangkan dari sisi pendidikan diominasi berpendidikan SMA 56\%. Dan Pendidikan Tinggi $24 \%$.

Selain deskripsi profil responden perlu diketahui juga intensitas kunjungan, image Kepulauan Bangka Belitung, Alasan Berkunjung, Kunjungan Bersama Siapa, dan alasan berkunjung untuk apa, berikut hasil survey lapangan dapat dijelaskan bahwa dari sisi intensitas kunujungan sebagaian besar pengunjung 1-2 kali sebanyak $60 \%$ artinya 
Nanang Wahyudin, Muhammad Faisal Akbar, dan Sugiharti : Identifikasi Prioritas

Pengembangan Agrowisata Bangka Botanical Garden (BBG) Kota Pangkalpinang

banyak pengunjung baru, dan sebanyak $40 \%$ melakukan kunjungan lebih dari 6 kali yang mengartikan berkunjung ulang cukup tinggi, pengunjung didominasi wisatawan lokal dari Kota Pangkalpinang dan kabupaten lain di Bangka Belitung sedangkan yang berasal dari luar Bangka Belitung hanya 8\%

Adapun Motif kunjungan ke Bangka Botanical Garden sebanyak $60 \%$ berkunjung untuk menikmati objek seperti suasana lingkungan yang rindang dengan pohon pinus yang rimbun dan obejek-objek utama lainnya. Sebanyak $48 \%$ berkunjung bersama keluarga dan sebanyak 44\% bersama teman, Bangka Botanical Garden merupakan satusatunya agrowista yang ada di Pangkalpinang dan telah dipilih pengunjung karena objek wisatanya sehingga mejadi pertimbangan utama dalam peningkatan objek maupun pemenuhan fasilitas pendukungnya.

\section{Analisis IPA (Importance Performance Analysis)}

Menurut Sever (2015), Importanceperformance analysis (IPA) adalah a useful tool in examining customer satisfaction and management strategies. This technique can help tourism stakeholders in diagnosing underlying deficiencies and setting priorities in tourism development. Analisis ini juga digunakan dalam penelitian Wijayanti (2015), Ivan Ka Wai Lai dan Michael Hitchcock,(2015), analisis IPA dimulai dari setiap indikator dan dilanjutkan setiap variabel penelitian, adapun hasil analisisnya sebagai berikut :

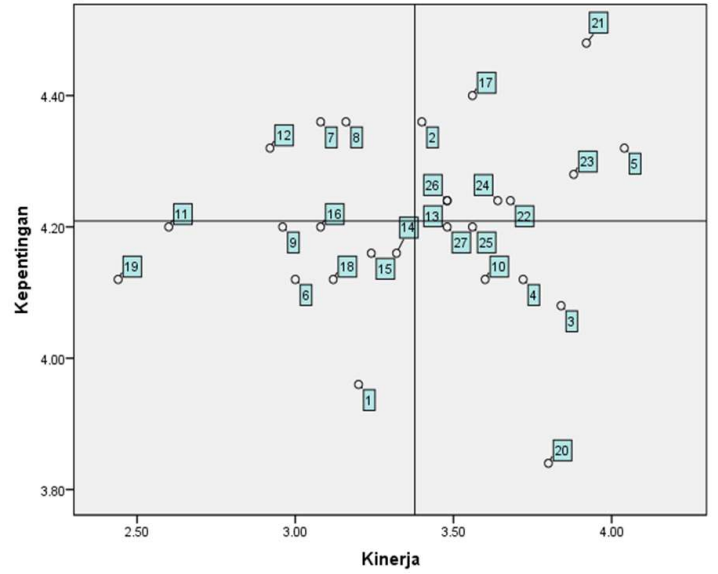

Gambar 2. Hasil Analisis Indikator
Hasil analisis dengan menggunakan alat bantu SPSS 22 memetakan indikator dari variabel, dengan penjelasan sebagai berikut: A : Pada kuadaran A menunjukan prioritas utama untuk segera dilakukan perbaikan, indikator yang masuk dalam kuadaran ini Menunjukkan faktor atau atribut yang sangat penting namun kenyataan yang diberikan jauh dari harapan wisatawan, mengartikan pihak pengelola belum melaksanakan sesuai dengan keinginan pengunjung sehingga mengecewakan/tidak puas. Indikator no 7 Kuantitas dan Kualitas Toilet, 8 Ketersediaan Tempat Sampah, 12 Kondisi Jalan Objek wisata.

Kuantitas dan kualitas Toilet dinilai sangat kurang karena kondisi eksisting hanya terdapat di satu tempat didekat objek rumah pondok danau, untuk itu seiring kesiapan peningkatan jumlah pengunjung maka fasilitas utama umum wajib segera diperbaiki. Ketersediaan tempat sampah dinilai masih kurang walapun telah ada dibebrapa titik namun secara kuantitas dinilai masih kurang. Kondisi jalan yang berkonsep jalan tanah namun kondisi tanah yang bergelombang dan becek saat hujan tentunya perlu dicarikan solusi, karena para pengunjung menilai kondisi tersebut sangat kurang baik.

B : Pada kuadran ini menunjukkan unsur jasa pokok yang telah berhasil dilaksanakan. Untuk itu wajib dipertahankannya. Dianggap sangat penting dan sangat memuaskan. Indikator 2. Keberdaan Danau dan Pondok-pondok, 5. Suasana Lingkungan Objek, 17. Tingkat Keamanan, 21. Tingkat Kebersihan, 22. Tingkat Pelayanan Pengelola, 23. Tingkat Kenyamanan, 24. Sifat Keramahtamahan, 26. Sifat Tolong Menolong.

Keberadaan Danau dan Pondokpondok dinilai sudah sangat bagus sehingga wajib dipertahankan namun 
Nanang Wahyudin, Muhammad Faisal Akbar, dan Sugiharti : Identifikasi Prioritas Pengembangan Agrowisata Bangka Botanical Garden (BBG) Kota Pangkalpinang

dari komentar pengunjung sebaiknya dikembangkan lagi seperti adanya perahu bebek-bebkan sehinga bisa jadi daya Tarik bagi para pengunjung. Suasana lingkungan objek dinilai sudah sangat baik yang mana para pengunjung merasa senang dan nyaman dengan suasana yang sejuk dan rindangnya pepohonan pinus. Tingkat Keamanan, Tingkat Kebersihan, Tingkat Pelayanan Pengelola, Tingkat Kenyamanan, Sifat Keramahtamahan, Sifat Tolong Menolong, di nilai sudah sangat baik sehingga kedepan cukup dipertahankan.

C : Pada kuadran ini (Perioritas Rendah) Menunjukkan pelaksanaannya oleh pengelola biasa-biasa saja, dianggap kurang penting dan kurang memuaskan namun demikian tetap membutuhkan perbaikan. Indikator no 1. Keberadaan Penjual sayur, Buah organik dan makanan 6.Ketersediaan Transportasi Menuju Wiasata, 9. Kelistrikan dan Penerangan, 11.Fasilitas Bermain, 14. Tempat parkir yang disediakan 15 . Pelayanan informasi yang disediakan,16. Pelayanan keamanan yang diberikan,18. Sumber Informasi,19.Ketersediaan Brosur Informasi Obyek Wisata

Keberadaan penjual sayur, buah Organic dan makanan dinilai sudah baik namun tetap perlu perbaikan, dengan mempertimbangkan konsep agrowisata sebaiknya kedepan adanya kebun yang bisa langsung dipanen oleh pengunjung yang hendak berbelanja maupun menikmati suasana kebun wisata. Ketersediaan Transportasi Menuju Wiasata memang menjadi salah satu masalah di Bangka Belitung mengingat angkutan umum di Pangkalpinang kurang berkembang baik dan secara khusus tidak ada transportasi umum/angkot menuju agrowisata hal tersebut tentunya perlu adanya kerjasama dengan berbagai pihak.
D : Menunjukkan faktor yang mempengaruhi pelanggan kurang penting, akan tetapi pelaksanaannya berlebihan. Dianggap kurang penting tetapi sangat memuaskan. (J. Supranto, 2006). Indikator 3 Keberadaan Ternak Sapi,4 Keberadaan Rumah Adat,10 Warung / Restoran,13 Kualitas Jaringan Telekomunikasi/internet,25 Sifat Keterbukaan,27 Sifat Kepedulian Terhadap Lingkungan. Keberadaan ternak sapi dan rumah adat dinilai sudah melebihi harapan pelanggan mengingat pelanggan menilai dua hal tersebut tidak terlalu penting, sehingga perbaikan untuk kedepan ialah adanya edukasi/peningkatan daya Tarik di objek keberdaan ternak sapi sehingga dapat meningkatkan tingkat kepentingan bagi pengunjung, sedangkan untuk rumah adat perlu adanya informasi/sejarah perihal rumah adat tersbut sehingga membuat pengunjung semakin tertarik, dan untuk indikator Kualitas Jaringan

Telekomunikasi/internet, Sifat Keterbukaan, Sifat Kepedulian Terhadap Lingkungan kesemuanya sudah memberikan tingkat kepuasan yang baik.

Berdasarkan hasil analisis penelitian ini sejalan dengan hasil penelitian (Mulyana Yayan dan Yulianto,(2018) sangat diperlukan perencanan, pengorganisasian, pengawasan dan peningkatan sumber daya manusia dan sarana prasarana yang mendukung baik yang disediakan oleh pihak pemerintah maupun pihak swasta, serta sejalan dengan hasil penelitian XueMing Zhang,(2012), memenuhi beragam kebutuhan wisatawan, membuka pasar wisata yang potensial, dan mengembangkan poin tambahan baru dari ekonomi pariwisata. Untuk itu memenuhi kebutuhan-kebutuhan wisatawan maka dengan memaksimalkan potensi yang dinilai lemah disetiap variabel maupun indikator pada objek wisata Bangka Botanical Garden. 
Nanang Wahyudin, Muhammad Faisal Akbar, dan Sugiharti : Identifikasi Prioritas

Pengembangan Agrowisata Bangka Botanical Garden (BBG) Kota Pangkalpinang

\section{KESIMPULAN}

Objek wisata Bangka Botanical Garden merupakan objek wisata sangat populer di kalangan wisatan lokal dan sangat mudah dijangkau untuk wisatawan nusantara karena letak yang sangat strategis karena berada di Kota Pangkalpingn, yang merupakan Ibu kota Provinsi Kepulauan Bangka Belitung sehingga menjadi pintu gerbang utama masuk ke Pulau Bangka, sehingga objek wisata Bangka Botanical Garden memiliki peluang yang sangat baik untuk dikembangkan menjadi objek wisata unggulan dan sangat mendukung pencapaian penghargaan Anugerah Pesona Indonesia pada Ajang Pariwisata Terpopuler Indonesia.

Berdasarkan hasil analisis deskriptif, disimpulkan pengunjung baru sangat tinggi dan yang melakukan kunjungan ulang wisatawan lokalpun cukup tinggi namun pengunjung dari luar daerah masih sangat minim, motif wisatawan ber kunjung ke BBG untuk menikmati objek wisata hal ini sudah sangat baik

Berdasarkan hasil analisis Important Performance Analysis maka yang menjadi prioritas utama untuk dilakukan perbaikan dan pengembangan di BBG yang tepat sasaran berdasarkan persepsi wisatawan yaitu indikator dari berbagai variabel yaitu kuantitas dan kualitas toilet, kondisi jalan objek wisata dan ketersediaan tempat sampah.

Dengan mempertimbangkan banyaknya pengunjung baru dan loyalitas pengunjung yang tinggi maka peningkatan sarana prasana menjadi hal utama yang perlu dilakukan seperti menambah jumlah tolilet dan tempat sampah serta memperbaiki jalan utama agar tetap keras dan tidak bergelombang, jumlah pengunjung dari luar daerah yang masih sangat minim maka program promosi perlu ditingkatkan lagi bisa dengan membranding BBG sebagai Agrowisata unggulan kota Pangkalpnang dan tentunya menambah objek baru di Agrowisata BBG tersbut seperti ada wisata bercocok tanam mapupun wisata memanen.

\section{UCAPAN TERIMAKASIH}

Saya ucapkan terimakasih kepada KEMENRISTEKDIKTI yang telah mendanai penelitian ini melalui hibah penelitian dosen pemula serta Lembaga Penelitian dan Pengabdian Kepada Masyarakat (LPPM) Universitas Bangka Belitung yang banyak memfasilitasi, serta tak lupa kepada tim peneliti dan seluruh surveyor yang banyak memabantu dilapangan sehingga terlaksananya penelitian ini.

\section{DAFTAR PUSTAKA}

Basiago, A. D. (1999). Economic, social, and environmental sustainability in development theory and urban planning practice. In The Environmentalist (Vol. 19). Kluwer Academic Publishers.

Chia-Lin Chang, Thanchanok Khamkaew, \& Michael Mcaleer. (2012). IV estimation of a panel threshold model of tourism specialization and economic development. Tourism Economics, $18(1), 5-41$.

Management, H., Bhagawat, P., Mahajana, M., \& Road, K. R. S. (2016). Significance of Domestic Tourism in India as a Major Revenue Generator. (Xxxviii), 6-9.

Wahyudin, N., Pratama, S., \& Faisal, M. (2019). An Exploration of Market Potential of Tourism Sector in Pangkalpinang and Local Tourists , Perception. Integrated Journal of Business and Economics.

Yunis, E. (2009). Tourism and employment.

Mulyana Yayan dan Yulianto, (2018),

Strategi Pengembangan Kawasan

Wisata Kuliner di Kalibawang dan

Samingaluh Kulonprogo Yogyakarta, Jurnal Manajemen Resort dan Leisure, Vol. 15, No. 1, April 2018,

Ivan Sever,(2015) Importance-performance analysis: A valid management tool?,Tourism Management,Volume 48,2015,Pages 43-53, ISSN 0261-5177, https://doi.org/10.1016/j.tourman.2014.1 0.022.(http://www.sciencedirect.com/sci ence/article/pii/S0261517714002222) 
Nanang Wahyudin, Muhammad Faisal Akbar, dan Sugiharti : Identifikasi Prioritas Pengembangan Agrowisata Bangka Botanical Garden (BBG) Kota Pangkalpinang

Ivan Ka Wai Lai, Michael Hitchcock,(2015)Importanceperformance analysis in tourism: $A$ framework for researchers, Journal Tourism Management, Volume 48, Pages 242-267,ISSN 0261-5177, https://doi.org/10.1016/j.tourman.2014.1 1.008.http://www.sciencedirect.com/scie nce/article/pii/S0261517714002374)

Wijayanti, T., Hubeis, M., \& Muksin, M. (2015). Marketing Strategies For Developing Agrotourism In Jember Regency. Indonesian Journal Of Business And Entrepreneurship (IJBE), 1(3), 148. doi:http://dx.doi.org/10.17358/ijbe.1.3.1 $\underline{48}$

XueMing Zhang,(2012)Research on the Development Strategies of Rural Tourism in Suzhou Based on SWOT Analysis,Energy Procedia,Volume 16, Part B,Pages 1295-1299, ISSN 18766102 ,

https://doi.org/10.1016/j.egypro.2012.01. 207.(http://www.sciencedirect.com/scien ce/article/pii/S1876610212002172)

\section{Buku}

Sugiyono. (2016). Metode Penelitian Kombinasi (Mixed Methods). Bandung: CV Alfabeta.

Sugiarto dkk.(2003) Teknik Sampling. Jakarta: PT Gramedia Pustaka Utama

BPS (Badan Pusat Statistik). (2018). Jumlah Kunjungan Tamu Asing dan Domestik di Kota Pangkalpinang.

\section{Internet}

http://www.anugerahpesonaindonesia.com/ca

tegory/most-popular-ecotoursim, diakses pada tanggal 8 Oktober 2019. 